\title{
Group-specific effects on coastal bacterioplankton of polyunsaturated aldehydes produced by diatoms
}

\author{
Cecilia Balestra1 ${ }^{1}$, Laura Alonso-Sáez ${ }^{2,3}$, Josep M. Gasol ${ }^{2}$, Raffaella Casotti ${ }^{1, *}$ \\ ${ }^{1}$ Stazione Zoologica A. Dohrn, Villa Comunale, 80121 Naples, Italy \\ ${ }^{2}$ Institut de Ciències del Mar, CSIC, Passeig Maritim de la Barceloneta 37-49, 08003 Barcelona, Catalonia, Spain
}

${ }^{3}$ Present address: Centro Oceanográfico de Xixón, Instituto Español de Oceanografía, Camín del L'Arbeyal s/n, 33212 Xixón, Spain

\begin{abstract}
Polyunsaturated aldehydes (PUAs), produced as secondary metabolites by diatoms, have been shown to induce toxic effects on a variety of organisms, including copepods and phytoand bacterioplankton. However, the nature of and the players in this interaction remain poorly understood. We tested the effect of 3 PUAs commonly produced by marine diatoms - 2E, $4 E / Z$-heptadienal (HEPTA), 2E,4E/Z-octadienal (OCTA), 2E,4E/Z-decadienal (DECA) and a mix of HEPTA and OCTA (MIX) - on a natural bacterial community from a coastal area of the NW Mediterranean Sea (Blanes Bay, Spain). Little effect on total or relative cell abundance or bulk bacterial production was observed after 6 or $24 \mathrm{~h}$ exposure to $7.5 \mathrm{nM}$ of the 3 different PUAs for the different bacterial phylogenetic groups (Gammaproteobacteria, Bacteroidetes, Rhodobacteraceae and SAR11), assessed by catalysed reporter deposition (CARD)-fluorescence in situ hybridisation (FISH). Metabolic activity, i.e. singlecell activity as determined by microautoradiography combined with CARD-FISH (MAR-CARDFISH), was least affected by the addition of single PUAs in Gammaproteobacteria, markedly in Bacteroidetes and most markedly in Rhodobacteraceae, leading to a decrease in Rhodobacteraceae abundance by $21 \%$ (by $38 \%$ of the active cells assessed by leucine uptake) compared to the control. Bacteroidetes, although markedly affected in single-cell activity, were the most abundant group ( $54 \%$ of total cell counts). The addition of a mixture of OCTA and HEPTA produced a more pronounced decrease in the metabolic activity of all groups than the incubation with the single PUAs, suggesting a synergistic effect. Our results demonstrate that PUAs have a differential effect on the single-cell activity of distinct bacterial groups in natural communities. PUAs may therefore play an important role in shaping bacterial community composition by conferring a competitive advantage to PUA-resistant groups, allowing them to preferentially use the organic matter released by diatoms.
\end{abstract}

KEY WORDS: PUAs · Bacterial composition · Metabolism · MAR-CARD-FISH · Diatoms

\section{INTRODUCTION}

Diatoms are responsible for $>50 \%$ of the total oceanic primary production (Mann 1999) and are a dominant fraction of the seasonal blooms that occur in the ocean. However, the biological bases of such ecological success are not completely understood. It has been demonstrated that diatom species produce volatile polyunsaturated aldehydes (PUAs), such as 2E,4E/Z-heptadienal (HEPTA), 2E,4E/Z-octadienal (OCTA), 2E, 4E/Z, 7Z-octatrienal, 2E,4E/Z-decadienal (DECA) and 2E,4E/Z,7Z-decatrienal (Wichard et al. 2005a), which can induce inhibitory effects on the reproduction of copepods (Miralto et al. 1999, Ianora et al. 2004) and the growth of various phytoplankton species (Casotti et al. 2005, Ribalet et al. 2007a). Several studies have reported that DECA also reduces the growth of pathogenic non-marine Bacteria (Bisignano et al. 2001, Adolph et al. 2004), and Ribalet et al. (2008) showed that 3 PUAs (DECA, HEPTA and OCTA) induced different effects on cultured marine Bacteria belonging to different taxonomical groups. In the later study, either no effect, growth inhibition at high concentrations, or even growth enhancement-probably because PUAs were acting as growth cofactors - were observed in different types of Bacteria. However, no 
general response patterns could be found for the dominant marine bacterioplankton groups (Alpha- and Gammaproteobacteria or Bacteroidetes), since different species within the same broad phylogenetic groups reacted differently to the PUAs.

The enzymatic cascade leading to PUA production has been shown to be activated within seconds after cell integrity is compromised, so that PUAs are not detected in intact cells (Pohnert 2000). However, substantial amounts of PUAs can be released at the end of the stationary phase of growth in cultures of Skeletonema marinoi right before culture decay $\left(376 \mathrm{nM}_{\text {; }}\right.$ Vidoudez \& Pohnert 2008), suggesting active production of PUA by intact cells. Wichard et al. (2005b) reported a PUA cell content of $47.7 \mathrm{fmol}^{\mathrm{PUA}}$ cell $^{-1}$ during a diatom bloom in the English Channel, and Ribalet et al. (2007a, 2009) demonstrated that PUA production in cultured $S$. marinoi dramatically increases with age and nutrient limitation, up to $27.5 \mathrm{fmol}$ PUA cell $^{-1}$. Also, PUAs dissolved in seawater have been detected and measured during a bloom of $S$. marinoi in the northern Adriatic Sea (Vidoudez et al. 2011).

In culture, different diatom species appear to harbour distinct bacterial communities (Grossart et al. 2005, Sapp et al. 2007), although the nature and dynamics of these interactions remain largely unknown. In situ, spatio-temporal changes in marine bacterial community composition have been frequently related with variations in chlorophyll a concentration (Murray et al. 1998, Pinhassi et al. 2004), suggesting a linkage with phytoplankton blooms. Altogether, these observations indicate that there are specific associations between species of Bacteria and phytoplankton. Since distinct bacterial groups appear to be differently affected by PUAs, the high local concentrations of these compounds in the surroundings of diatoms could be partly responsible for the observed succession of phylotypes during blooms in the environment. Considering that Bacteria are responsible for the remineralisation of the organic matter produced by phytoplankton, investigating the factors modulating their community composition and metabolic activity may help in elucidating the details of this close interaction.

Here, we expand current knowledge by testing the effects of 3 common diatom-derived PUAs on a natural bacterial community from a coastal site in the western Mediterranean Sea. We used 3 PUAs available commercially, which are also commonly produced by Skeletonema marinoi, and a combination of them in the same proportion as found for this diatom when in culture (Ribalet et al. 2007b), with the aim of mimicking the concentration and composition of PUAs present at sea when a diatom bloom collapses. We measured the effects of the PUAs on bulk bacterial metabolic activity and on the single-cell activity of the dominant bacterial groups by means of microautoradiography combined with catalysed reporter deposition-fluorescence in situ hybridization (MAR-CARD-FISH). The combination of different single-cell techniques, such as flow cytometry, with molecular ones, such as microautoradiography and fluorescence in situ hybridization (MAR-FISH) represents a very powerful tool to assess the metabolic activity of the different components of natural communities.

\section{MATERIALS AND METHODS}

Sampling site and experimental design. We sampled a shallow (20 m depth), oligotrophic site located $\sim 800 \mathrm{~m}$ offshore of Blanes (Catalonia, Spain) in the NW Mediterranean $\left(41^{\circ} 39.90^{\prime} \mathrm{N}, 2^{\circ} 48.03^{\prime} \mathrm{E}\right.$, the Blanes Bay Microbial Observatory). Background information from this site exists on bacterial diversity (Alonso-Sáez et al. 2007b) and activity (Alonso-Sáez et al. 2008).

Twenty litres of surface seawater were taken on 24 April 2007, filtered through a $200 \mu \mathrm{m}$ nylon mesh size net to eliminate large organisms, and transported under dim light to the laboratory within $2 \mathrm{~h}$. Twenty millilitres of seawater were dispensed into each of 24 polycarbonate sterile flasks (Falcon). The flasks were kept at $19^{\circ} \mathrm{C}$ in a temperature-controlled chamber. Four flasks were inoculated with $7.5 \mathrm{nmol}^{-1}$ (final conc.) of HEPTA, and 4 others, with $7.5 \mathrm{nmol} \mathrm{l}^{-1}$ (final conc.) of OCTA. Six flasks were inoculated with $7.5 \mathrm{nmol} \mathrm{l}^{-1}$ (final conc.) of DECA, and 4 additional flasks, with $4.2 \mathrm{nmol} \mathrm{l}^{-1}$ of HEPTA plus $3.3 \mathrm{nmol}^{-1}$ of OCTA (MIX). Six flasks were used as controls, receiving no additions, but treated and analysed as all the other flasks. All PUAs were obtained from Sigma-Aldrich. The concentrations of PUAs used in the experiments were based on estimates of total PUA production by the diatom Skeletonema marinoi under phosphate (P) limitation (7.5 fmol cell ${ }^{-1}$ of OCTA and HEPTA; Ribalet et al. 2007a) and the average concentration of this species during a bloom in the northern Adriatic Sea $\left(10^{7}\right.$ cell $1^{-1}$; Casotti \& Bastianini unpubl. data). Assuming that a maximum of $10 \%$ of total cells lyse during blooms, the amount of PUA released per litre of seawater would be $7.5 \mathrm{nmol}$, which is the amount used in the experiments, and represents the average PUA concentration to which planktonic organisms might be exposed around S. marinoi cells blooming at sea.

One flask of each series was used for the MARCARD-FISH analyses, and the others, for measuring in duplicate bacterial abundances, 5-cyano-2,3-ditolyl tetrazolium chloride (CTC; Polysciences) reduction and bulk bacterial production.

At the beginning of the experiment $\left(t_{0}\right)$ only the bacterial abundances were determined, while after $6 \mathrm{~h}$ all 
the parameters were measured. The samples inoculated with DECA were also sampled after $24 \mathrm{~h}$ of incubation for all parameters and after $48 \mathrm{~h}$ for bacterial production and CTC reduction only.

Bacterial concentrations. Bacterial concentrations were determined by flow cytometry following Marie et al. (1999). Samples $(1.6 \mathrm{ml})$ were fixed with a mix of paraformaldehyde (1\%) and glutaraldehyde $(0.05 \%)$ for $10 \mathrm{~min}$ in the dark, frozen in liquid nitrogen and stored at $-80^{\circ} \mathrm{C}$ for $1 \mathrm{~d}$. Thawed samples were stained with SYBR Green I (Molecular Probes) for $10 \mathrm{~min}$ in the dark at room temperature and analysed using a FACSCalibur flow cytometer (Becton Dickinson), weighting the sample before and after the run to determine the analysed volume. Regions were established on the side scatter (SSC) versus FL1 (green fluorescence) plots in order to discriminate HNA (high nucleic acid content) from LNA (low nucleic acid content) bacterial cells (Gasol \& del Giorgio 2000).

Bacterial single-cell activity. Of each sample, $200 \mu \mathrm{l}$ were incubated with CTC (5 mM final conc.) for $90 \mathrm{~min}$ in the dark at room temperature and then analysed by flow cytometry to detect the number of highly active bacterial cells. CTC is a redox dye that is reduced by actively respiring cells to insoluble fluorescent formazan (CTF). CTC-positive cells emit a red fluorescence when excited by blue light. The presence of CTF is indicative of the presence of an active electron transport system (Gasol \& Arístegui 2007).

Bulk bacterial activity. Bulk bacterial activity rates were estimated using the $\left[{ }^{3} \mathrm{H}\right]$-leucine (Leu) incorporation method of Kirchman et al. (1985), modified as described in Smith \& Azam (1992). Briefly, for each sample, 4 aliquots $(1.2 \mathrm{ml})$ were incubated in Eppendorf tubes with $\left[{ }^{3} \mathrm{H}\right]$-Leu (TRK636, Amersham; 40 nM final conc.). We added $120 \mu \mathrm{l}$ of trichloroacetic acid (TCA, 5\% final conc.) to the negative controls before addition of Leu. The tubes were incubated for 2 to $3 \mathrm{~h}$ in a temperature-controlled chamber. The incorporation was stopped with the addition of $120 \mu$ l of cold $50 \% \mathrm{TCA}$, and samples were frozen at $-20^{\circ} \mathrm{C}$ until processing (within $2 \mathrm{~d}$ ). After TCA rinsing, the samples were resuspended in $1 \mathrm{ml}$ of scintillation cocktail (Optimal HiSafe, Perkin Elmer) and kept in the dark for $24 \mathrm{~h}$ before counting with a scintillation counter (LS6500 Beckman Coulter).

Bacterial community composition. Catalysed reporter deposition (CARD)-FISH was used to determine bacterial community composition following the protocol of Pernthaler et al. (2002). Samples were fixed overnight with formaldehyde $(1 \%)$ and stored at $4{ }^{\circ} \mathrm{C}$. From each sample, $5 \mathrm{ml}$ were gently filtered onto $0.2 \mu \mathrm{m}$ white polycarbonate filters (GTTP, $25 \mathrm{~mm}$ diameter; Millipore) supported by a cellulose nitrate filter (HAWP, $0.45 \mathrm{~mm}$ diameter; Millipore), washed twice with Milli-Q water, dried and stored at $-20^{\circ} \mathrm{C}$ until processing. To avoid cell loss during permeabilisation, filters were dipped in low-gelling-point agarose $(0.1 \%)$, dried face up on Parafilm on a glass plate at $37^{\circ} \mathrm{C}$ and dehydrated with ethanol (95\%) for $1 \mathrm{~min}$. For cell-wall permeabilisation, filters were incubated with lysozyme (Sigma) for $1 \mathrm{~h}$ at $37^{\circ} \mathrm{C}$ and then with achromopeptidase (Sigma) for $30 \mathrm{~min}$.

Several horseradish peroxidase (HRP)-oligonucleotide probes were used to characterise the composition of the microbial community in the original water samples. Probes were: Eub 338-II-III, which target most Bacteria (EUB) (Amann et al. 1990, Daims et al. 1999); Gam42, which targets most Gammaproteobacteria (GAMMA) (Manz et al. 1992); CF319a, which targets a relatively large group of Bacteria belonging to the Cytophaga-Flavobacterium-Bacteroides (CFB) group (phylum Bacteroidetes; Manz et al. 1996); Ros537, which targets members of the Roseobacter-Sulfitobacter-Silicibacter (Rhodobacteraceae) (ROS) group (Eilers et al. 2001); and SAR11, which targets the SAR11 cluster (Morris et al. 2002). All probes were purchased from biomers.net.

Hybridisations were carried out at $35^{\circ} \mathrm{C}$ overnight, and specific hybridisation conditions were ensured by adding $45 \%$ formamide for the SAR11 probe and $55 \%$ for the other probes to the hybridisation buffer. Filters were washed for $5 \mathrm{~min}\left(37^{\circ} \mathrm{C}\right)$ in prewarmed washing buffer, incubated for $15 \mathrm{~min}$ at $46^{\circ} \mathrm{C}$ in $1 \mathrm{ml}$ of amplification buffer with $4 \mu \mathrm{l}$ of tyramide conjugated with Alexa 488 (1 mg ml ${ }^{-1}$, Alexa Fluor; Molecular Probes) containing $p$-iodophenylboronic acid (20 $\mathrm{mg} \mathrm{mg}^{-1}$ tyramide). Finally, filter sections were mounted in a Citifluor-VectaShield (Vector Labs) mixture (4:1) containing 4'-6'-diamidino-2-phelylindole (DAPI, final conc. $1 \mu \mathrm{g} \mathrm{ml}^{-1}$ ) and visualised in an epifluorescence microscope (Axioskop 2 microscope, Carl Zeiss GmbH). Between 500 and 1000 DAPIstained cells were counted per sample in a minimum of 10 fields. For each microscope field, 2 different categories were enumerated: total DAPI-stained cells (on average $>600$ sample $^{-1}$ ) and cells stained with the specific probe.

Bacterial group-specific activity. MAR-CARD-FISH was used to measure the single-cell activity of the bacterial groups following the protocol described by Alonso \& Pernthaler (2005). Samples were incubated with [ ${ }^{3} \mathrm{H}$ ]-Leu (20 $\mathrm{nM}$ final conc.) for $4 \mathrm{~h}$ in a temperature-controlled chamber. At the end of the incubation, samples were filtered and hybridised following the CARD-FISH protocol detailed in 'Bacterial community composition'. After the hybridisation procedure, filters were glued onto glass slides with an epoxy adhesive (UHU plus; UHU GmbH). The slides were embedded in tempered photographic emulsion 

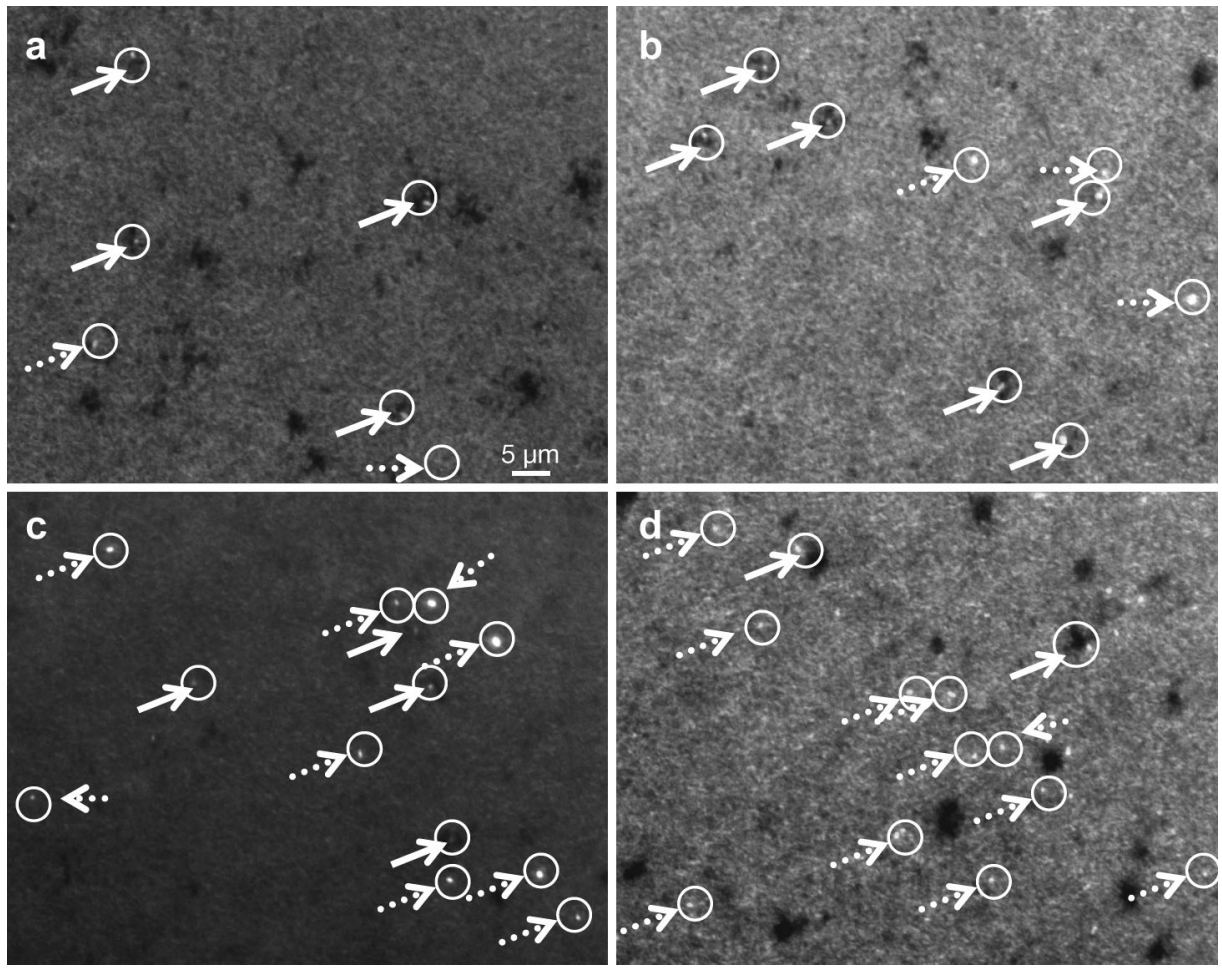

Fig. 1. Phylogenetic group-specific $\left[{ }^{3} \mathrm{H}\right]$-leucine incorporation. Combined epifluorescence and transmitted light micrographs showing bacterial cells positive to the different oligonucleotide fluorescent probes (white), specific for phylogenetic groups: (a) Rhodobacteraceae, (b) Gammaproteobacteria, (c) SAR11 and (d) Bacteroidetes, as marked by CARD-FISH (see 'Materials and methods'). FISH-positive (fluorescent) Bacteria in the circles are considered active (filled arrows) when associated with dark silver grains, or non-active, when not associated with silver grains (dotted arrows)

(NTB-2, Kodak) containing $0.1 \%$ agarose in a dark room at $46^{\circ} \mathrm{C}$, placed on an ice-cold metal bar for ca. 5 min to allow the emulsion to solidify and stored in black boxes at $4^{\circ} \mathrm{C}$ until development. The optimal exposure time was determined empirically for each treatment and averaged $12 \mathrm{~h}$. The exposed slides were dipped for $3 \mathrm{~min}$ into the developer (D19, Kodak), rinsed with distilled water for $30 \mathrm{~s}$, fixed for 3 min in fixer (Tmax, Kodak) and then washed for 5 min with tap water. The slides were dried in a desiccator overnight at room temperature, and a cover slide was glued on top with a drop of mounting solution (1 Citifluor:4 VectaShield). The samples were examined under an epifluorescence microscope (Axioskop 2 microscope) for a positive reaction to the CARD-FISH probe, while the presence of silver grains around the cells was detected by using the transmission mode of the same microscope. Fig. 1 shows representative images of microautoradiography of each phylogenetic group: Rhodobacteraceae, Gammaproteobacteria, SAR11 and Bacteroidetes. The dark silver-grain halos surrounding cells indicate cells that have incorporated the radioactive Leu.

\section{RESULTS}

\section{Bacterial abundance, physiology and bulk heterotrophic production}

Initial bacterial concentrations were $9.95 \times 10^{5} \pm$ $1.90 \times 10^{4}$ cells $\mathrm{ml}^{-1}$. In short-term incubations $(6 \mathrm{~h})$ Bacteria grew by $13 \%$ in OCTA and HEPTA, $5 \%$ in DECA and $7 \%$ in the MIX treatments, compared to $t_{0}$ (Table 1). After $24 \mathrm{~h}$, an increase in bacterial abundance of $31 \%$ with respect to the initial value was detected in the DECA treatment (Fig. 2a).

After $6 \mathrm{~h}$ of incubation, no significant differences in the percent contribution of HNA and LNA Bacteria to the total Bacteria, nor in the percent CTC+ cells with respect to the controls were detected, except for the OCTA treatment, which induced a decrease in CTC+ cells $(89 \pm 3 \%$; Table 1$)$. In the longer exposures with DECA, CTC+ Bacteria represented $78 \%( \pm 14 \%)$ after $24 \mathrm{~h}$ and $55 \%( \pm 10 \%)$ after $48 \mathrm{~h}$ of incubation (Fig. 2a), with respect to the controls. Water samples were filtered through a $200 \mu \mathrm{m}$ nylon mesh prior to incubations, in order to eliminate large grazers. Although we 

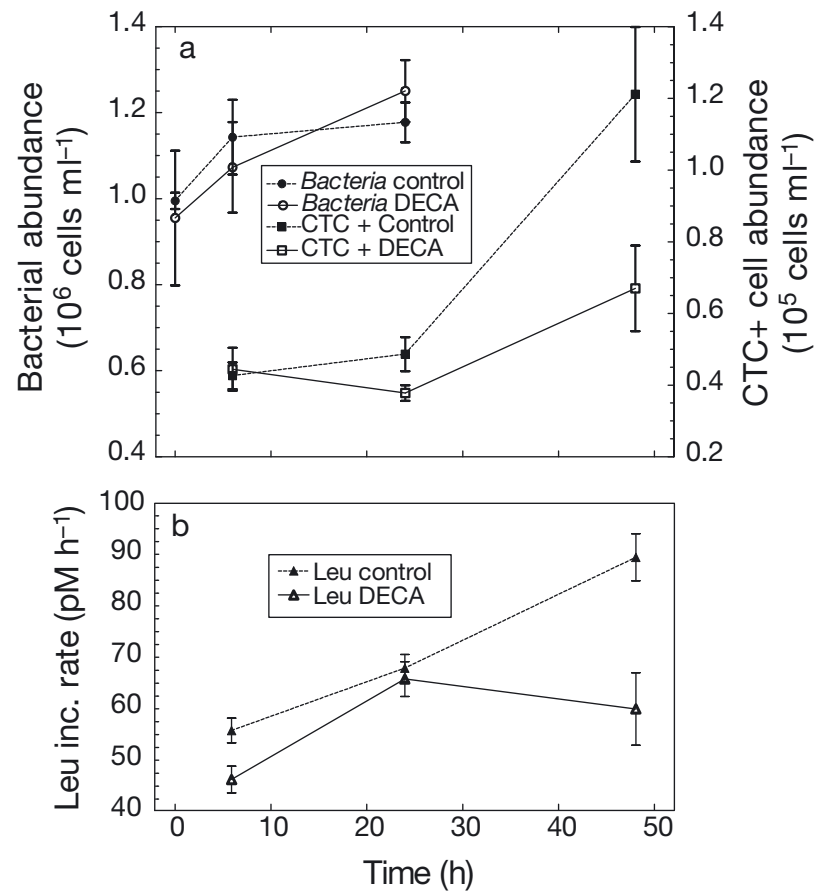

Fig. 2. (a) Time evolution of bacterial concentrations (cell $\mathrm{ml}^{-1}$ ) in control samples and in samples incubated with $7.5 \mathrm{nmol} \mathrm{l}^{-1}$ of $2 E, 4 E / Z$-decadienal (DECA) for up to $24 \mathrm{~h}$ (left axis) and time evolution of 5-cyano-2,3-ditolyl tetrazolium chloride (CTC)-positive bacterial concentrations (cell ml ${ }^{-1}$ ) in samples incubated with $7.5 \mathrm{nmol}^{-1}$ of DECA for up to $48 \mathrm{~h}$ (right axis). (b) Leucine incorporation rates $\left(\mathrm{pmol} \mathrm{l^{-1 }} \mathrm{h}^{-1}\right.$ ) in control samples and in samples incubated with $7.5 \mathrm{nmol} \mathrm{l}^{-1}$ of $\mathrm{DECA}$ for up to $48 \mathrm{~h}$. Error bars represent $\pm \mathrm{SD}$

cannot exclude the possibility that smaller grazers were feeding upon Bacteria in the samples, Fig. 2 shows that after $24 \mathrm{~h}$ of incubation the bacterial abundance increased similarly in the controls and in the treated samples. In our view, this suggests that the effect of grazing was not too important, or, at least, the 2 treatments were not differently affected by grazers. The same was true for the CTC+ series. In all shortterm treatments $(6 \mathrm{~h})$, Leu incorporation decreased with respect to the controls (Table 1), as it also did after $24 \mathrm{~h}$ in the DECA treatment (Fig. 2b).

\section{Bacterial community composition}

After $6 \mathrm{~h}$ of incubation, $79 \%$ of cell counts could be detected with the Eub338 probe suite. Bacteroidetes was the most abundant group (CFB, 49\% of total cells), followed by similar amounts of SAR11 and Gammaproteobacteria (21 and 18\% of total cells, respectively). Rhodobacteraceae were present at lower abundances (ROS, $12 \%$ of total cells; Table 2). The proportion of the different groups did not show dramatic changes after PUA exposure, but the SAR11 contribution decreased in the HEPTA and OCTA treatments (Student's $t$-test: $\mathrm{p}<0.05$ ), while Rhodobacteraceae decreased in the DECA and the MIX series with respect to the controls (Student's $t$-test: $\mathrm{p}<0.05$; Table 2). After $24 \mathrm{~h}$ of DECA exposure, both SAR11 and Rhodobacteraceae showed lower abundances with respect to the controls (Student's $t$-test: $\mathrm{p}<0.05$ and $\mathrm{p}<0.01$, respectively).

\section{Group-specific bacterial activity}

In the control samples, despite the fact that Bacteroidetes and SAR11 dominated the community, they were underrepresented in the contribution to activity in Leu uptake, while Gammaproteobacteria were low in numbers but showed high activity (Fig. 3). After $6 \mathrm{~h}$ in the MIX, proportions did not change, but percent contribution to total activity decreased (Fig. 3).

After $6 \mathrm{~h}$ of incubation, the percent Leu incorporation in Gammaproteobacteria increased following DECA and OCTA addition, while a reduction was observed for all taxonomic groups investigated in comparison to the control, except for SAR11 with DECA (Fig. 4a). In general, the relative activity of Gammaproteobacteria was the least affected, while the activities of Rhodobacteraceae and Bacteroidetes were the most affected by the PUAs. In the HEPTA and OCTA treatments, a comparable decrease in Leu uptake activity was detected for SAR11, Rhodobacteraceae

Table 1. Bacterial abundance (BA), percentage of high nucleic acid (HNA) Bacteria, 5-cyano-2,3-ditolyl tetrazolium chloride (CTC)-positive cell abundance and leucine (Leu) incorporation rate (LIR) in samples incubated for $6 \mathrm{~h}$ with different polyunsaturated aldehydes. HEPTA: 2E,4E/Z-heptadienal; OCTA: 2E,4E/Z-octadienal; DECA: 2E,4E/Z-decadienal; MIX: a mix of HEPTA and OCTA. Values are means $\pm \mathrm{SD}(\mathrm{n}=3)$

\begin{tabular}{|lcccc|}
\hline Treatment & $\begin{array}{c}\text { BA } \\
(\text { cells ml }\end{array}$ & HNA $)$ & CTC+ & LIR \\
$(\%)$ & $\left(\right.$ cells ml $\left.^{-1}\right)$ & $\begin{array}{c}\text { (pmol Leu l } \\
\left(\mathrm{h}^{-1}\right)\end{array}$ \\
\hline Control & $1.14 \times 10^{6} \pm 8.69 \times 10^{4}$ & $87 \pm 0.13$ & $4.26 \times 10^{4} \pm 3.73 \times 10^{3}$ & $55.77 \pm 2.38$ \\
HEPTA & $1.13 \times 10^{6} \pm 2.67 \times 10^{4}$ & $78 \pm 1.56$ & $4.45 \times 10^{4} \pm 2.59 \times 10^{3}$ & $47.57 \pm 1.10$ \\
OCTA & $1.14 \times 10^{6} \pm 2.52 \times 10^{4}$ & $86 \pm 0.11$ & $3.81 \times 10^{4} \pm 1.12 \times 10^{3}$ & $47.98 \pm 1.79$ \\
DECA & $1.07 \times 10^{6} \pm 1.05 \times 10^{5}$ & $81 \pm 0.21$ & $4.44 \times 10^{4} \pm 6.00 \times 10^{3}$ & $46.24 \pm 2.59$ \\
MIX & $1.05 \times 10^{6} \pm 1.61 \times 10^{5}$ & $82 \pm 0.06$ & $4.07 \times 10^{4} \pm 1.40 \times 10^{3}$ & $50.22 \pm 0.83$ \\
\hline
\end{tabular}


Table 2. Percentages of the different eubacterial groups identified by CARD-FISH in the different treatments (see Table 1) $6 \mathrm{~h}$ after inoculation of polyunsaturated aldehydes (PUAs) and $24 \mathrm{~h}$ after inoculation with DECA. GAMMA: Gammaproteobacteria; SAR11: the SAR11 clade; ROS: Rhodobacteraceae; CFB: the Cytophaga-Flavobacterium-Bacteroides group. Values are means $\pm \mathrm{SD}$

\begin{tabular}{|c|c|c|c|c|}
\hline Treatment & GAMMA & SAR 11 & ROS & CFB \\
\hline \multicolumn{5}{|c|}{$6 \mathrm{~h}$ after inoculation of PUAs } \\
\hline Control & $18.0 \pm 2.1$ & $21.0 \pm 0.0$ & $12.0 \pm 0.9$ & $49.0 \pm 1.8$ \\
\hline HEPTA & $17.0 \pm 0.0$ & $17.0 \pm 0.9$ & $11.0 \pm 0.0$ & $55.0 \pm 0.9$ \\
\hline OCTA & $18.0 \pm 0.7$ & $18.0 \pm 0.8$ & $10.0 \pm 0.0$ & $54.0 \pm 0.8$ \\
\hline DECA & $20.0 \pm 1.4$ & $22.0 \pm 0.9$ & $9.0 \pm 0.0$ & $49.0 \pm 0.9$ \\
\hline MIX & $18.0 \pm 0.0$ & $22.0 \pm 1.8$ & $8.0 \pm 0.0$ & $52.0 \pm 1.8$ \\
\hline \multicolumn{5}{|c|}{$24 \mathrm{~h}$ after inoculation of DECA } \\
\hline Control & $19.0 \pm 1.4$ & $20.0 \pm 0.0$ & $12.0 \pm 0.9$ & $49.0 \pm 0.9$ \\
\hline DECA & $21.0 \pm 1.4$ & $15.0 \pm 5.1$ & $9.0 \pm 0.0$ & $55.0 \pm 0.9$ \\
\hline
\end{tabular}

bols), indicating a synergistic effect of the PUAs when inoculated together. Rhodobacteraceae and Bacteroidetes were still the most affected groups, in terms of the percentage of active cells. The activity of Gammaproteobacteria also showed a large reduction $(46.9 \pm 6.7 \%)$, while SAR11 was relatively the least affected bacterial group (Fig. 4). The net community effect of exposure to the PUAs was that the Gammaproteobacteria benefited in all cases, except in the MIX and HEPTA treatments. In the short-term (6 h) DECA treatment, SAR11 cells also benefited from the reduction of activity in the other bacterial groups (except Gammaproteobacteria). and Bacteroidetes. The short-term exposure $(6 \mathrm{~h})$ to DECA did not affect the activity of SAR11 and Gammaproteobacteria, but for Rhodobacteraceae and Bacteroidetes the abundance of active cells was reduced by $50 \%$ when compared to the controls. After $24 \mathrm{~h}$ of DECA exposure, the number of active SAR11 cells was reduced by $27.3 \%( \pm 12.7 \%)$ with respect to the controls, while Gammaproteobacteria still remained unaffected (Fig. 4b).

In the MIX treatment, we observed a dramatic effect, with an average reduction of the proportion of active cells in all bacterial groups (Fig. 3, open sym-

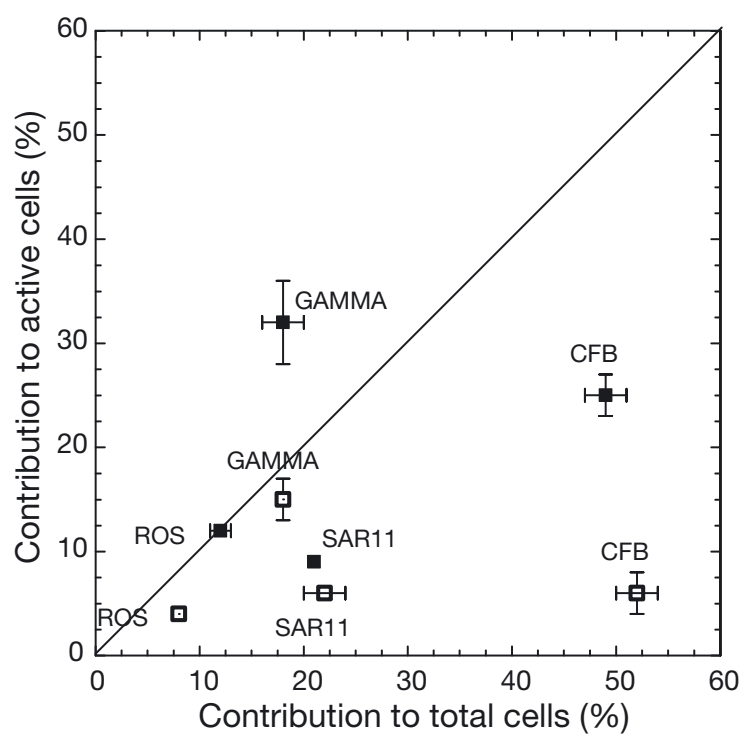

Fig. 3. Percent contribution (mean $\pm \mathrm{SD}$ ) of the 4 phylogenetic groups (abbreviations as in Table 2) to total and to active Bacteria in control samples (filled symbols) and in the MIX (2E,4E/Z-heptadienal and $2 E, 4 E / Z$-octadienal) treatment after $6 \mathrm{~h}$ of incubation with polyunsaturated aldehydes (open symbols)

\section{DISCUSSION}

Marine phytoplankton and Bacteria live in close association, potentially affecting the dynamics and succession patterns of each other. During the final stages of diatom blooms, cells lyse, releasing PUAs into the

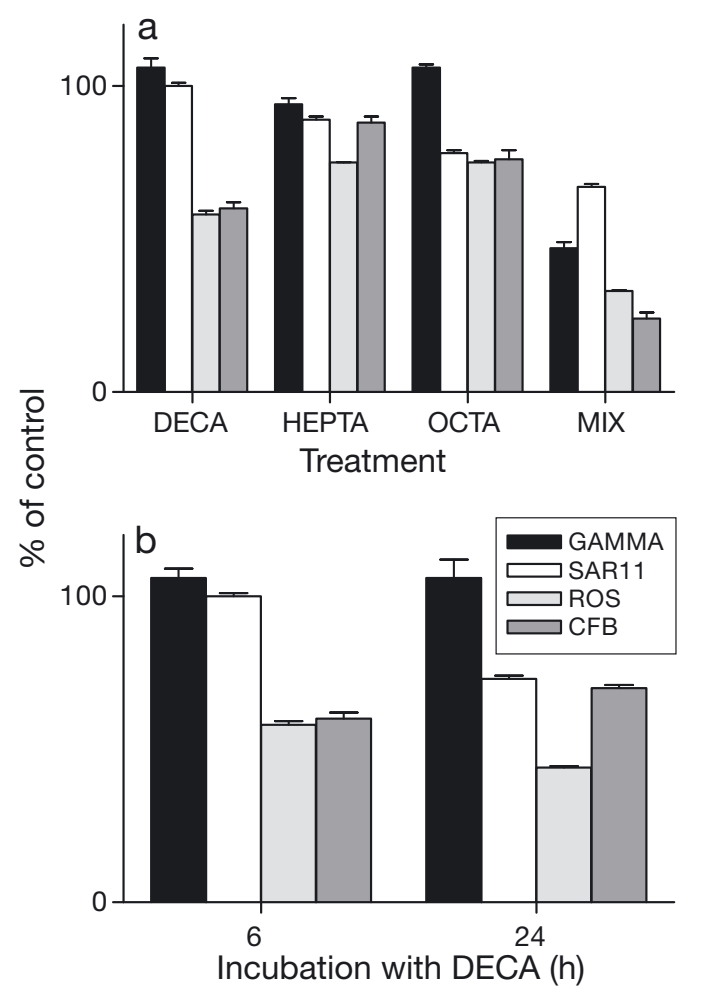

Fig. 4. (a) Phylogenetic group-specific $\left[{ }^{3} \mathrm{H}\right]$-leucine incorporation (in \% of control) after $6 \mathrm{~h}$ of incubation with differently polyunsaturated aldehydes (PUAs; for group and treatment abbreviations see Tables $1 \& 2$ ). (b) Metabolically active Bacteria (in \% of control) in the DECA treatments after 6 and $24 \mathrm{~h}$ of incubation. Error bars represent $\pm \mathrm{SD}$ 
environment; thus, the Bacteria surrounding them are exposed to high local concentrations of these potentially toxic compounds. In culture, the addition of PUAs has been shown to stimulate, inhibit, or have a neutral effect on the growth of different marine bacterial isolates (Ribalet et al. 2008), but, remarkably, the effect of PUAs on different bacterial groups has never previously been tested in situ. In the present study, we did not detect a strong effect of PUAs on the total abundance or percentage of HNAs or the actively respiring cells of natural bacterial communities after short-term incubations (i.e. $6 \mathrm{~h}$ ). This suggests that the bulk of natural Bacteria were initially resistant to these concentrations of PUAs, or that the effect was buffered internally as a result of both positive and negative effects on different taxonomic groups of Bacteria. Indeed, when analysed at a more specific level, we found clear differences in the Leu uptake activity of different bacterial groups (Gammaproteobacteria, Rhodobacteraceae and Bacteroidetes), with the net result being a significant reduction in bacterial production due to the addition of PUAs.

Gammaproteobacteria growth was not reduced by the addition of single PUAs (i.e. DECA, HEPTA, or OCTA), and their metabolic activity was actually even stimulated. In fact, previous observations from culture studies report that some members of this group may use PUAs as a source of carbon (Ribalet et al. 2008). The abundance of Gammaproteobacteria has also been shown to increase in natural blooms (AlonsoSáez et al. 2007a), which could be at least partially related to their resistance to PUAs. The low sensitivity of this group to PUAs might be the result of a compensatory mechanism among the species present, or an indication of the presence of highly resistant species within the group.

The Bacteroidetes was the most abundant group in situ, and, while their abundance was not affected by the addition of PUAs, their activity in Leu uptake was strongly reduced. This is surprising, since some studies have reported high abundance of Bacteroidetes during diatom bloom decay in marine (Riemann et al. 2000, Grossart et al. 2005) and freshwater systems (Salcher et al. 2010). Indeed, this group is known to use complex compounds of dissolved organic matter (polymeric substrates, combined amino acids) derived from senescent phytoplankton (Kirchman 2002). Bacteroidetes also comprise a large percentage of the Bacteria attached to diatoms in cultures (Pinhassi et al. 2004, Grossart et al. 2005) and are very responsive to the inputs and chemical changes of phytoplankton-dissolved organic carbon (Riemann et al. 2000, Fandino et al. 2001). The fact that only some diatoms are known to produce the PUAs used in the present study (Wichard et al. 2005a) could explain the difference between our results and the previously reported association of Bacteroidetes with diatoms in the environment (Grossart et al. 2005).

Rhodobacteraceae were present at a lower abundance (ca. 10\%), as is typical at this site, although MAR-FISH studies have shown that this is a metabolically very active group (Alonso \& Pernthaler 2005, Alonso-Sáez \& Gasol 2007, Malmstrom et al. 2007, Alonso-Sáez et al. 2008). In the present study, their activity with respect to Leu uptake was not very high, and they were also the group most affected by the PUAs. This is consistent with results of Ribalet et al. (2008), who found that some strains of Alphaproteobacteria, and in particular Roseobacter litoralis, were sensitive to low concentrations of PUAs. This alphaproteobacterial group dominates the free-living bacterial fraction in diatom cultures (Grossart et al. 2005) and seems to benefit from phytoplankton growth (Teira et al. 2008). Indeed, the dynamics of Rhodobacteraceae abundance have been reported to follow the development of phytoplankton biomass in nature (Eilers et al. 2001, Alonso-Sáez et al. 2007b). However, no detailed investigation of this group during PUA-producing diatom bloom development and decay is available, and it is possible that, while profiting, in general, from the organic matter from phytoplankton, these Bacteria are sensitive to diatom degradation products, such as PUAs. It is indeed possible that Rhodobacteraceae are able to develop resistance against toxic compounds when released gradually, as in natural conditions, as opposed to when they are challenged by acute inoculation, as in our study.

In our study, the SAR 11 clade, a subgroup of the Alphaproteobacteria, was one of the most abundant (ca. $21 \%$ ) groups, similar to previous reports for Blanes Bay (Alonso-Sáez et al. 2007b). Indeed, SAR 11 has been considered the most abundant phylogenetic group in the ocean (Morris et al. 2002) and appears to play a significant role in the processing of carbon (Malmstrom et al. 2004, Alonso-Sáez \& Gasol 2007). In our experiments, we observed that neither the abundance nor the metabolic activity of SAR11 was affected by DECA and that they were only slightly affected by the other PUAs (i.e HEPTA, OCTA and MIX). The low sensitivity of this group to PUAs suggests that they may take advantage of the growth reduction experienced by the other bacterial groups in the presence of these compounds. Such low sensitivity may also be related to its capability to adapt to different environmental conditions (Giebel et al. 2009), which facilitates its widespread abundance in all oceans.

It is remarkable that the metabolic activity of all of the taxonomic groups of Bacteria was more strongly affected by the mixture of different PUAs (MIX) than by the single PUAs. This suggests that the 2 PUAs used (OCTA and HEPTA) have a strong synergistic effect on 
Bacteria when inoculated together. This has important ecological implications, as PUAs are always released simultaneously by diatoms (Fontana et al. 2007). In general, the studies that have tested PUA toxicity on Bacteria have used exposures to single PUAs (Bisignano et al. 2001, Ribalet et al. 2008), which means that the synergistic effects of PUAs may have been underestimated. This additive effect was not observed by Vidoudez \& Pohnert (2008) in a diatom culture, although they used very low PUA concentrations. The difference could be due to a higher threshold for toxicity in Bacteria than in diatoms or to other unknown environmental biotic or biotic factors acting on natural communities and modulating the response to PUAs.

Our experiments indicate that PUAs released by diatoms likely play a role in driving the metabolic activity of environmental Bacteria with neutral, positive, or negative responses, depending on the phylogenetic group of Bacteria examined. This may shape the bacterioplankton community composition and, therefore, potentially, the ecosystem functioning in areas dominated by PUA-producing diatoms. Resistance to PUAs may confer a competitive advantage, by increasing the chances to use the organic matter released by diatoms; this mechanism may underlie the observed group succession during the evolution of a diatom bloom. However, the fact that one of the groups most sensitive to PUAs, the Bacteroidetes, is also commonly associated with decaying diatom blooms suggests that the key players of this complex interaction are not clear yet. The response to PUAs may also vary depending on the previous history of the bacterial community in terms of exposure to these compounds and the specific phase of the bloom. In addition, the environmental factors, such as temperature, light, nutrient availability, species composition, strongly modulate bacterial metabolism, as well as phytoplankton physiology, and the extent to which these factors rule the interaction between Bacteria and diatoms still remain to be determined.

Acknowledgements. The project was carried out within the framework and with the support of MarBEF (Network of Excellence in Marine Biodiversity and Ecosystem Functioning). J.M.G. was supported by grants SUMMER (CTM200803309/MAR) and STORM (CTM2009-09352/MAR). The Stazione Zoologica A. Dohrn and the University of Messina are acknowledged for travel support to C.B. T. Lefort is acknowledged for his technical help with flow cytometry measurements, and V. Balagué, C. Cardelús and I. Forn, for organisation of the sampling at the BBM Observatory.

\section{LITERATURE CITED}

Adolph S, Bach S, Blondel M, Cueff A and others (2004) Cytotoxicity of diatom-derived oxylipins in organisms belonging to different phyla. J Exp Biol 207:2935-2946
Alonso C, Pernthaler J (2005) Incorporation of glucose under anoxic conditions by bacterioplankton from coastal North Sea surface waters. Appl Environ Microbiol 71:1709-1716

Alonso-Sáez L, Gasol JM (2007) Seasonal variation in the contributions of different bacterial groups to the uptake of low-molecular-weight compounds in northwestern Mediterranean coastal waters. Appl Environ Microbiol 73: 3528-3535

> Alonso-Sáez L, Aristegui J, Pinhassi J, Gómez-Consarnau L and others (2007a) Bacterial assemblage structure and carbon metabolism along a productivity gradient in the NE Atlantic Ocean. Aquat Microb Ecol 46:43-53

Alonso-Sáez L, Balagué V, Sá EL, Sánchez O and others (2007b) Seasonality in bacterial diversity in north-west Mediterranean coastal waters: assessment through clone libraries, fingerprinting and FISH. FEMS Microbiol Ecol 60:98-112

Alonso-Sáez L, Vazquez-Dominguez E, Cardelús C, Pinhassi $\mathrm{J}$ and others (2008) Factors controlling the year-round variability in carbon flux through bacteria in a coastal marine system. Ecosystems 11:397-409

- Amann RI, Binder BJ, Olson RJ, Chisholm SW, Devereux R, Stahl DA (1990) Combination of $16 \mathrm{~S}$ ribosomal RNA targeted oligonucleotide probes with flow cytometry for analyzing mixed microbial population. Appl Environ Microbiol 56:1919-1925

- Bisignano G, Lagana MG, Trombetta D, Arena S and others (2001) In vitro antibacterial activity of some aliphatic aldehydes from Olea europaea L. FEMS Microbiol Lett 198: 9-13

Casotti R, Mazza S, Brunet C, Vantrepotte V, Ianora A, Miralto A (2005) Growth inhibition and toxicity of the diatom aldehyde 2-trans, 4-trans-decadienal on Thalassiosira weissflogii (Bacillariophyceae). J Phycol 41:7-20

Daims H, Bruhl A, Amann R, Schleifer KH, Wagner M (1999) The domain-specific probe EUB338 is insufficient for the detection of all Bacteria: development and evaluation of a more comprehensive probe set. Syst Appl Microbiol 22: 434-444

Eilers H, Pernthaler J, Peplies J, Glockner FO, Gerdts G, Amann R (2001) Isolation of novel pelagic bacteria from the German Bight and their seasonal contributions to surface picoplankton. Appl Environ Microbiol 67: 5134-5142

Fandino LB, Riemann L, Steward GF, Long RA, Azam F (2001) Variations in bacterial community structure during a dinoflagellate bloom analyzed by DGGE and 16S rDNA sequencing. Aquat Microb Ecol 23:119-130

- Fontana A, d'Ippolito G, Cutignano A, Miralto A, Ianora A, Romano G, Cimino G (2007) Chemistry of oxylipin pathways in marine diatoms. Pure Appl Chem 79:481-490

Gasol JM, Arístegui J (2007) Cytometric evidence reconciling the toxicity and usefulness of CTC as a marker of bacterial activity. Aquat Microb Ecol 46:71-83

> Gasol JM, del Giorgio PA (2000) Using flow cytometry for counting natural planktonic bacteria and understanding the structure of planktonic bacterial communities. Sci Mar 64:197-224

> Giebel HA, Brinkhoff T, Zwisler W, Selje N, Simon M (2009) Distribution of Roseobacter RCA and SAR11 lineages and distinct bacterial communities from the subtropics to the Southern Ocean. Environ Microbiol 11:2164-2178

> Grossart HP, Levold F, Allgaier M, Simon M, Brinkhoff T (2005) Marine diatom species harbour distinct bacterial communities. Environ Microbiol 7:860-873

- Ianora A, Miralto A, Poulet SA, Carotenuto Y and others (2004) Aldehyde suppression of copepod recruitment in 
blooms of a ubiquitous planktonic diatom. Nature 429: 403-407

Kirchman DL (2002) The ecology of Cytophaga-Flavobacteria in aquatic environments. FEMS Microbiol Ecol 39:91-100

Kirchman D, Knees E, Hodson R (1985) Leucine incorporation and its potential as a measure of protein synthesis by bacteria in natural aquatic systems. Appl Environ Microbiol 49:599-607

Malmstrom RR, Kiene RP, Cottrell MT, Kirchman DL (2004) Contribution of SAR11 bacteria to dissolved dimethylsulfoniopropionate and amino acid uptake in the North Atlantic Ocean. Appl Environ Microbiol 70:4129-4135

Malmstrom RR, Straza TRA, Cottrell MT, Kirchman DL (2007) Diversity, abundance, and biomass production of bacterial groups in the western Arctic Ocean. Aquat Microb Ecol 47:45-55

Mann DG (1999) The species concept in diatoms. Phycologia 38:437-495

Manz W, Amann R, Ludwig W, Wagner M, Schleifer KH (1992) Phylogenetic oligodeoxynucleotide probes for the major subclasses of Proteobacteria. Problems and solutions. Syst Appl Microbiol 15:593-600

Manz W, Amann R, Ludwig W, Vancanneyt M, Schleifer KH (1996) Application of a suite of 16S rRNA-specific oligonucleotide probes designed to investigate bacteria of the phylum Cytophaga-Flavobacter-Bacteroides in the natural environment. Microbiology 142:1097-1106

Marie D, Partensky F, Vaulot D, Brussaard C (1999) Enumeration of phytoplankton, bacteria and viruses in marine samples. In: Robinson JP (ed) Current protocols in cytometry. John Wiley \& Sons, New York, NY, p 11.11.111.11.15

Miralto A, Ianora A, Poulet SA, Romano G, Buttino I, Scala S (1999) Embryonic development in invertebrates is arrested by inhibitory compounds in diatoms. Mar Biotechnol 1:401-402

Morris RM, Rappé MS, Connon SA, Vergin KL, Siebold WA, Carlson CA, Giovannoni SJ (2002) SAR11 clade dominates ocean surface bacterioplankton communities. Nature 420: 806-810

Murray AE, Preston CM, Massana R, Taylor LT, Blakis A, Wu K, DeLong EF (1998) Seasonal and spatial variability of bacterial and archaeal assemblages in the coastal waters near Anvers Island, Antarctica. Appl Environ Microbiol 64:2585-2595

Pernthaler A, Pernthaler J, Amann R (2002) Fluorescence in situ hybridization and catalyzed reporter deposition for the identification of marine bacteria. Appl Environ Microbiol 68:3094-3101

Pinhassi J, Sala MM, Havskum H, Peters F, Guadayol O, Malits A, Marrasé C (2004) Changes in bacterioplankton composition under phytoplankton regimens. Appl Environ Microbiol 70:6753-6766

Editorial responsibility: Hans-Georg Hoppe, Kiel, Germany
Pohnert G (2000) Wound-activated chemical defense in unicellular planktonic algae. Angew Chem Int Ed 39: 4352-4354

Ribalet F, Berges JA, Ianora A, Casotti R (2007a) Growth inhibition of cultured marine phytoplankton by toxic algalderived polyunsaturated aldehydes. Aquat Toxicol 85: 219-227

Ribalet F, Wichard T, Pohnert G, Ianora A, Miralto A, Casotti $\mathrm{R}(2007 \mathrm{~b})$ Age and nutrient limitation enhance polyunsaturated aldehyde production in marine diatoms. Phytochemistry 68:2059-2067

Ribalet F, Intertaglia L, Lebaron P, Casotti R (2008) Differential effect of three polyunsaturated aldehydes on marine bacterial isolates. Aquat Toxicol 86:249-255

Ribalet F, Vidoudez C, Cassin D, Pohnert G, Ianora A, Miralto A, Casotti R (2009) High plasticity in the production of diatom-derived polyunsaturated aldehydes under nutrient limitation: physiological and ecological implications. Protist 160:444-451

Riemann L, Steward GF, Azam F (2000) Dynamics of bacterial community composition and activity during a mesocosm diatom bloom. Appl Environ Microbiol 66:578-587

Salcher MM, Pernthaler J, Posch T (2010) Spatiotemporal distribution and activity patterns of bacteria from three phylogenetic groups in an oligomesotrophic lake. Limnol Oceanogr 55:846-856

> Sapp M, Wichels A, Gerdts G (2007) Impacts of cultivation of marine diatoms on the associated bacterial community. Appl Environ Microbiol 73:3117-3120

Smith DC, Azam F (1992) A simple, economical method for measuring bacterial protein synthesis rates in seawater using ${ }^{3} \mathrm{H}$-leucine. Mar Microb Food Webs 6:107-114

Teira E, Gasol JM, Aranguren-Gassis M, Fernández A, González J, Lekunberri I, Álvarez-Salgado XA (2008) Linkages between bacterioplankton community composition, heterotrophic carbon cycling and environmental conditions in a highly dynamic coastal ecosystem. Environ Microbiol 10:906-917

> Vidoudez C, Pohnert G (2008) Growth phase-specific release of polyunsaturated aldehydes by the diatom Skeletonema marinoi. J Plankton Res 30:1305-1313

Vidoudez C, Casotti R, Bastianini M, Pohnert G (2011) Quantification of dissolved and particulate polyunsaturated aldehydes in the Adriatic Sea. Marine Drugs (in press)

- Wichard T, Poulet SA, Halbsand-Lenk C, Albaina A, Harris R, Liu D, Pohnert G (2005a) Survey of the chemical defence potential of diatoms: screening of fifty species for $\alpha, \beta, \gamma, \delta$ unsaturated aldehydes. J Chem Ecol 31:949-958

Wichard T, Poulet SA, Pohnert G (2005b) Determination and quantification of $\alpha, \beta, \gamma, \delta$-unsaturated aldehydes as pentafluorobenzyl-oxime derivates in diatom cultures and natural phytoplankton populations: application in marine field studies. J Chromatogr B 814:155-161

Submitted: May 28, 2010; Accepted: December 21, 2010 Proofs received from author(s): March 23, 2011 